\title{
Effect of Phosphorus, Biofertilizers and Organic Manures on Root Nodulation and Productivity of Green Gram (Vigna radiata L.)
}

\author{
G. Bhavya*, K. Chandra Shaker, G. Jayasree and M. Malla Reddy \\ Department of Soil Science and Agricultural Chemistry, Agricultural College, Poalsa, Jagtial \\ Professor Jayashankar Telangana State Agricultural University, Telangana State, India \\ *Corresponding author
}

\section{A B S T R A C T}

Field experiment was conducted during kharif, 2016 on sandy loam soil to study the effect of phosphorus levels, biofertilizers (PSB) and organic manures (vermicompost) on dry

\section{Keywords}

Integrated phosphorus management, Green gram, PSB,

vermicompost, nodule number

Article Info

Accepted:

06 May 2018

Available Online:

10 June 2018 matter production at flowering, total root nodule number, effective root nodule number and yield of green gram. The experiment was laid out in randomized block design with three replications having 12 treatment combinations viz. 3 levels of phosphorus $(0,75$ and 100 $\%$ RDP) and its integration with PSB (500 $\mathrm{g} \mathrm{ha}^{-1}$ seed) and vermicompost (5 $\left.\mathrm{t} \mathrm{ha}^{-1}\right)$. A significant increase in dry matter production at flowering was recorded with the application of $100 \%$ RDP along with PSB and vermicompost. Application of $100 \%$ RDP $\mathrm{ha}^{-1}$ along with vermicompost and PSB seed inoculation $\left(\mathrm{T}_{12}\right)$ recorded significantly highest number of total and effective root nodules plant ${ }^{-1}(12.63,19.1$ and 25.1 total nodules $\mathrm{pl}^{-1}$ and $6.83,10.1$ and 12.97 effective nodule $\mathrm{pl}^{-1}$ during $3^{\text {rd }}, 4^{\text {th }}$ and $5^{\text {th }}$ weeks after sowing, respectively). Combined application of $100 \%$ RDP along with PSB and vermicompost registered significantly highest grain $\left(1626 \mathrm{~kg} \mathrm{ha}^{-1}\right)$ and haulm yield (1033 $\mathrm{kg} \mathrm{ha}^{-1}$ ) in green gram. The treatment control (without $\mathrm{P}$ fertilization) showed significantly poor performance in dry matter production and yield of green gram as against the rest of the treatments.

\section{Introduction}

India is the largest producer of pulses in the world. Green gram is one of the most ancient and extensively grown leguminous crops of India. Green gram is an excellent source of high quality of protein. It also contains high quality of lysine $(4600 \mathrm{mg} / \mathrm{g} \quad \mathrm{N})$ and tryptophan $(60 \mathrm{mg} / \mathrm{g} \mathrm{N})$ and consumed as whole grain or as well as in the form of dal for table purpose. Green gram is supposed to be easily digestible, hence preferred by patients. The sprouted seeds of green gram are rich in ascorbic acid (vitamin C), riboflavin and Thiamine (Dhakal et al., 2016). In India, green gram represents $18 \%$ (34.4 lakh hectares) of total pulse area and $11.48 \%$ (514 lakh tonnes) of pulse production (CMIE, 2014-15). Despite occupying a greater position both in respect of area and production, the productivity of green gram is low compared to world average. One reason for this could be the imbalanced nutrient management.

Phosphorus is one of the most essential elements for living organism and is the second 
largest agricultural chemical needed by plant for growth and development. It is need by leguminous crops for rapid and healthy root development. It hastens the maturity and increases the rate of nodulation and pod development (Rani et al., 2016). Plant utilizes $0.1 \%$ of phosphorus present in soil and rest is rapidly fixed as insoluble forms. Beneficial microbes resident to the rhizosphere are receiving greater attention, as they can solubize inorganic phosphate into soluble form through the process of acidification, chelation, exchange reactions and production of organic acids. In addition to these phosphate solubilising microorganisms can also increase the growth of plants by other mechanisms i.e. production of phyto hormones such as IAA which promotes plant growth (Vibha et al., 2014). Organic manures like vermicompost stimulate the phosphomonoesterase activity in the crop rhizosphere. Hence, the present work aimed at studying the effect of combined application of organic and inorganic sources of $\mathrm{P}$ on yield and nodulation of green gram.

\section{Materials and Methods}

A field experiment was conducted during Kharif, 2016 at College Farm, Agricultural College, Professor Jayashankar Telangana State Agricultural University, Polasa, Jagtial, Telangana State. The soil of the experimental field was sandy loam in texture and slightly alkaline in reaction ( $\mathrm{pH}$ 7.84) having an organic carbon content of $0.364 \%, 157.5 \mathrm{~kg}$ available nitrogen $\mathrm{ha}^{-1}, 18.6 \mathrm{~kg}$ available $\mathrm{P}_{2} \mathrm{O}_{5}$ $\mathrm{ha}^{-1}, 164.8 \mathrm{~kg}$ available $\mathrm{K}_{2} \mathrm{O} \mathrm{ha}{ }^{-1}$, and $19.4 \mathrm{~kg}$ available sulphur $\mathrm{ha}^{-1}$. The experiment was laid out in randomized block design with three levels of phosphorus (0, 75 and $100 \%$ RDP) and its integration with biofertilizers (PSB) and organic manures (vermicompost), all together 12 treatments replicated thrice. The various treatments were control $\left(\mathrm{T}_{1^{-}}\right.$without any $\mathrm{P}$ application), seed inoculation of PSB
$\left(\mathrm{T}_{2}\right)$, application of vermicompost @ $5 \mathrm{t} \mathrm{ha}^{-1}$ $\left(\mathrm{T}_{3}\right), \mathrm{PSB}+$ vermicompost $\left(\mathrm{T}_{4}\right), 75 \% \mathrm{RDP}$ $\left(\mathrm{T}_{5}\right), 75 \% \mathrm{RDPP}+\mathrm{PSB}\left(\mathrm{T}_{6}\right), 75 \% \mathrm{RDP}+$ vermicompost $\left(\mathrm{T}_{7}\right), 75 \% \mathrm{RDP}+\mathrm{PSB}+$ vermicompost $\left(\mathrm{T}_{8}\right), 100 \% \mathrm{RDP}\left(\mathrm{T}_{9}\right), 100 \%$ $\mathrm{RDP}+\mathrm{PSB}\left(\mathrm{T}_{10}\right), \quad 100 \% \mathrm{RDP}+$ vermicompost $\left(\mathrm{T}_{11}\right)$ and $100 \% \mathrm{RDP}+\mathrm{PSB}+$ vermicompost $\left(\mathrm{T}_{12}\right)$. The plots are uniformly basal dressed with $20 \mathrm{~kg}$ urea and $20 \mathrm{~kg} \mathrm{~K}_{2} \mathrm{O}$ $\mathrm{ha}^{-1}$ and phosphorus applied as per the treatments. PSB and vermicompost applied as per the treatments. Rhizobium seed treatment was given to all the treatments. The green gram variety LGG 460 was sown with a spacing of $30 \mathrm{~cm}$ X $10 \mathrm{~cm}$. The soil and plant samples from individual treatmental plots were collected and analyzed for dry matter production at flowering, total and effective root nodule number at three stages of crop growth and yield of green gram.

\section{Results and Discussion}

\section{Dry matter production}

Significant increase in dry matter production at flowering was observed with the combined application of inorganic $\mathrm{P}$, vermicompost and PSB (Table 1). Application of $100 \%$ RDP along with PSB and vermicompost $\left(\mathrm{T}_{12}\right)$ increased the drymatter production by 43.14 percent as against control $\left(\mathrm{T}_{1}\right)$, which was recorded the drymatter production of $596 \mathrm{~kg}$ $\mathrm{ha}^{-1}$. The drymatter recorded in $\mathrm{T}_{12}$ treatment $\left(853 \mathrm{~kg} \mathrm{ha}^{-1}\right)$ was statistically on par with the treatments of $\mathrm{T}_{9}(100 \% \mathrm{RDP}), \mathrm{T}_{10}(100 \%$ $\mathrm{RDP}+\mathrm{PSB})$ and $\mathrm{T}_{11}(100 \% \mathrm{RDP}+$ Vermicompost) treatments. Plant dry matter production is a result of growth and environment interaction through leaves, stems and reproductive parts which contributes to dry matter. Increasing inorganic P levels from) to $75 \%$ RDP significantly increased the dry matter production. This is due to better utilization of $\mathrm{P}$ in the presence of higher dose of $\mathrm{P}$. Phosphorus is known to play a beneficial 
role in legume growth by promoting extensive root development and nodulation and thereby increasing the supply of nutrients to growing parts of plant resulting in an increased photosynthetic area and dry matter accumulation. These results are in accordance with earlier reports of Dhewa et al., (2015) and Das et al., (2015).

Significant differences in dry matter production were not observed between $T_{9}$ and $\mathrm{T}_{8}$ treatments. The dry matter production in $100 \%$ RDP $\left(813 \mathrm{~kg} \mathrm{ha}^{-1}\right)$ was statistically on par with the dry matter production of $75 \%$ RDP + PSB + vermicompost $\left(795 \mathrm{~kg} \mathrm{ha}^{-1}\right)$. The results indicate that $25 \% \mathrm{P}$ fertilizer may be saved by applying PSB and vermicompost. This may be attributed to inorganic $\mathrm{P}$ when applied to soil get transformed to various reaction products mainly remaining in sparingly soluble orthophosphates. On the contrary, if it is applied with vermicompost and $\mathrm{PSB}$, fixed $\mathrm{P}$ will be dislodged thus resulting in the enhanced $\mathrm{P}$ availability to the plants (Kadam et al., 2014). These results in support with those of Tak et al., (2013) and Jat et al., (2012).

\section{Nodule number}

The data of root nodule number (Table 2) revealed application of phosphorus, vermicompost and seed inoculation of PSB significantly increased the total and effective root nodules. Total number of nodules plant ${ }^{-1}$ were significantly higher under the treatment $\mathrm{T}_{12}$ (12.63, 19.1 and 25.1 total root nodules $\mathrm{pl}^{-1}$ were recorded during $4^{\text {th }}, 5^{\text {th }}$ and $6^{\text {th }}$ weeks after sowing, respectively). In contrast, the control plot $\left(T_{1}\right)$ was recorded lowest number of total root nodules $\mathrm{pl}^{-1}$ during $4^{\text {th }}, 5^{\text {th }}$ and $6^{\text {th }}$ weeks after sowing which were $7.9,13.5$ and 16.0 respectively. Increasing the inorganic $\mathrm{P}$ level from 0 to $100 \%$ RDP significantly increased the root nodule number during entire crop growth.

Table.1 Dry matter production and yield of green gram as influenced by inorganic P levels, organic manures and PSB treatments

\begin{tabular}{|c|c|c|c|}
\hline Treatments & $\begin{array}{c}\text { Dry matter } \\
\text { production at } \\
\text { flowering }\left(\mathrm{kg} \mathrm{ha}^{-1}\right)\end{array}$ & $\begin{array}{l}\text { Haulm yield } \\
\qquad\left(\mathrm{kg} \mathrm{ha}^{-1}\right)\end{array}$ & $\begin{array}{l}\text { Grain yield } \\
\left(\mathrm{kg} \mathrm{ha}^{-1}\right)\end{array}$ \\
\hline $\begin{array}{l}\mathrm{T}_{1} \text { - Control (without } \\
\text { application of } \mathbf{P} \text { ) }\end{array}$ & 596 & 993 & 703 \\
\hline $\mathrm{T}_{2^{-}} \mathbf{P S B}$ & 615 & 1037 & 724 \\
\hline $\mathrm{T}_{3}$-Vermicompost & 621 & 1067 & 750 \\
\hline $\mathrm{T}_{4}$-PSB + Vermicompost & 631 & 1157 & 771 \\
\hline $\mathrm{T}_{5}-75 \% \mathrm{RDP} \mathrm{ha}^{-1}$ & 778 & 1259 & 831 \\
\hline $\mathrm{T}_{6}-\mathrm{T}_{5}+\mathrm{PSB}$ & 753 & 1275 & 853 \\
\hline $\mathrm{T}_{7}-\mathrm{T}_{5}+$ Vermicompost & 782 & 1380 & 869 \\
\hline$T_{8}-T_{5}+$ PSB+ Vermicompost & 795 & 1412 & 929 \\
\hline $\mathrm{T}_{9-100} \% \mathrm{RDP} \mathrm{ha}^{-1}$ & 813 & 1457 & 957 \\
\hline $\mathrm{T}_{10}-\mathrm{T}_{9+\mathrm{PSB}}$ & 822 & 1518 & 985 \\
\hline $\mathrm{T}_{11}-\mathrm{T}_{9}+$ Vermicompost & 830 & 1566 & 996 \\
\hline$T_{12-} T_{9}+$ PSB+ Vermicompost & 853 & 1626 & 1033 \\
\hline $\mathrm{CD}(0.05)$ & 47 & 88 & 56 \\
\hline SE(D) & 22.76 & 42.37 & 27.17 \\
\hline
\end{tabular}


Table.2 Total and effective root nodule number of green gram as influenced by inorganic $\mathrm{P}$ levels, organic manures and PSB treatments

\begin{tabular}{|c|c|c|c|c|c|c|}
\hline \multirow[t]{2}{*}{ Treatments } & \multicolumn{2}{|c|}{$4^{\text {th }}$ week } & \multicolumn{2}{|c|}{$5^{\text {th }}$ week } & \multicolumn{2}{|c|}{$6^{\text {th }}$ week } \\
\hline & $\begin{array}{c}\text { Total } \\
\text { nodules }\end{array}$ & $\begin{array}{c}\text { Effective } \\
\text { nodules }\end{array}$ & $\begin{array}{c}\text { Total } \\
\text { nodules }\end{array}$ & $\begin{array}{c}\text { Effective } \\
\text { nodules }\end{array}$ & $\begin{array}{c}\text { Total } \\
\text { nodules }\end{array}$ & $\begin{array}{c}\text { Effective } \\
\text { nodules }\end{array}$ \\
\hline $\begin{array}{l}T_{1} \text { - Control (without } \\
\text { application of } P \text { ) }\end{array}$ & 7.90 & 4.03 & 13.50 & 6.07 & 16.00 & 6.97 \\
\hline $\mathrm{T}_{2-}$ PSB & 8.27 & 4.37 & 14.60 & 6.60 & 16.67 & 8.17 \\
\hline$T_{3}$-Vermicompost & 8.60 & 4.50 & 14.80 & 6.77 & 17.23 & 8.40 \\
\hline $\mathrm{T}_{4}$-PSB + Vermicompost & 8.77 & 4.60 & 15.30 & 7.20 & 17.80 & 8.80 \\
\hline $\mathrm{T}_{5}-75 \% \mathrm{RDP}^{-1}$ & 8.93 & 4.75 & 15.73 & 7.70 & 18.83 & 9.10 \\
\hline $\mathrm{T}_{6}-\mathrm{T}_{5}+\mathrm{PSB}$ & 9.00 & 5.10 & 16.33 & 7.97 & 20.30 & 9.40 \\
\hline$T_{7}-T_{5}+$ Vermicompost & 10.17 & 5.60 & 16.93 & 8.07 & 21.70 & 10.17 \\
\hline $\mathrm{T}_{8}-\mathrm{T}_{5}+\mathrm{PSB}+$ Vermicompost & 11.43 & 5.97 & 17.57 & 8.53 & 22.50 & 10.53 \\
\hline $\mathrm{T}_{9-100} \% \mathrm{RDP} \mathrm{ha}^{-1}$ & 11.63 & 6.23 & 18.10 & 8.93 & 23.10 & 10.70 \\
\hline $\mathrm{T}_{10}-\mathrm{T}_{9}+\mathrm{PSB}$ & 11.90 & 6.37 & 18.40 & 9.00 & 24.07 & 11.50 \\
\hline $\mathrm{T}_{11}-\mathrm{T}_{9}+$ Vermicompost & 12.13 & 6.63 & 18.77 & 9.37 & 24.50 & 12.07 \\
\hline $\mathrm{T}_{12^{-}} \mathrm{T}_{9}+\mathrm{PSB}+$ Vermicompost & 12.63 & 6.83 & 19.10 & 10.10 & 25.10 & 12.97 \\
\hline CD & 0.245 & 0.139 & 0.159 & 0.135 & 0.167 & 0.181 \\
\hline SE(D) & 0.118 & 0.06 & 0.077 & 0.065 & 0.080 & 0.08 \\
\hline
\end{tabular}

Phosphorus helps in increase in various metabolic processes, such as cell division, cell development and cell enlargement which increase the root length and nodule number (Ahamad et al., 2014). Similar results have been reported by Kumawat et al., (2010) in green gram and Kumar et al., (2014) in black gram crop. Combined application of PSB or/and vermicompost further improved root nodule number during nodule formation period.

Integration of $100 \%$ RDP, PSB and vermicompost $\left(T_{12}\right)$ significantly increased the active root nodule number to $6.83,10.10$ and 12.97 as against 4.03, 6.07 and 6.97 nodules plant ${ }^{-1}$ with control $\left(\mathrm{T}_{1}\right)$ during $4^{\text {th }}, 5^{\text {th }}$ and $6^{\text {th }}$ weeks after sowing respectively.

Seed inoculation with PSB also significantly increased the total and active nodule plant ${ }^{-1}$ over uninoculated treatments. This increase is due to PSB release of growth promoting substances by PSB which provide favorable environment for rhizobium, which promotes root nodulation (Rathour et al., 2014) and also PSB solubilises the native $\mathrm{P}$ and enhance its availability to the plants. The increased availability might have helped in better nodulation. These results are similar to the findings of Kumawat et al., 2010. Vermicompost decreases $\mathrm{P}$ fixation and enhances $\mathrm{P}$ availability, thus resulting in better growth and consequently exploitation of greater soil volume for root nodulation (Choudary et al., 2011). These results are in agreement with finding of Tak et al., (2013) and Singh et al., (2013).

\section{Yield of green gram}

The grain yield and haulm yield significantly influenced by different phosphorus management practices (Table 1). The seed yield was the highest when vermicompost and PSB were combined applied with inorganic P 
at $100 \% \mathrm{RDP}\left(\mathrm{T}_{12}\right)$, the yield being 1033.33 $\mathrm{kg} \mathrm{ha}^{-1}$ and it was found to be on par with $\mathrm{T}_{11}$ (996 kg ha-1) and T10 (985.00 kg ha $\mathrm{kg}^{-1}$ treatments. Integrated application of inorganic $\mathrm{P}$ along with vermicompost and PSB significantly increased the seed yield by $46.92 \%\left(\mathrm{~T}_{12}\right.$ on $\left.\mathrm{T}_{1}\right), 11.75 \%\left(\mathrm{~T}_{8}\right.$ on $\left.\mathrm{T}_{5}\right)$ and 8 $\%\left(\mathrm{~T}_{12}\right.$ on $\left.\mathrm{T}_{9}\right)$ at $\mathrm{P}_{0} \cdot \mathrm{P}_{75}$ and $\mathrm{P}_{100}$ levels, respectively over inorganic $\mathrm{P}$ application at their respective level. Application of $75 \%$ RDP alone $\left(T_{5}\right)$ significantly increased the seed yield to $831.00 \mathrm{~kg} \mathrm{ha}^{-1}$ over $703.33 \mathrm{~kg}$ $\mathrm{ha}^{-1}$ in control $\left(\mathrm{T}_{1}\right)$. The increased seed yield with $\mathrm{P}$ application might be due to increased $P$ availability and uptake resulted profuse nodulation leading to greater symbiotic nitrogen fixation which in turn has positive effect on photosynthesis, then on yield (Rani et al., 2016 and Kumar et al., 2014). Haulm yield was increased from a value of $993.33 \mathrm{~kg}$ ha- 1 in the control $\left(\mathrm{T}_{1}\right)$ to $1625.66 \mathrm{~kg} \mathrm{ha}^{-1}$ in the treatment $\left(\mathrm{T}_{12}\right)$ which was receiving 100 $\%$ RDP along with vermicomost and PSB and it was on par with $\mathrm{T}_{11}$ treatments. However, addition of $75 \%$ RDP alone $\left(\mathrm{T}_{5}\right)$ significantly increased the haulm yield to $1259.33 \mathrm{~kg} \mathrm{ha}^{-1}$ over control $\left(\mathrm{T}_{1}\right)$. Rathour et al., (2014) reported that phosphorus involves in cell division, increases various metabolic processes and cell enlargement, application of phosphate solubilising bacteria releases growth promoting substances which improves the haulm yield.

\section{References}

Ahamad, S., Singh, R., Sharma, K.K and Gupta, A. 2014. Effect of vermicompost and phosphorus on performance of green gram [Vigna radiata (I) wilczek] grown under loamy sand soil. Agrotechnology. 2(4): 277.

Choudhary, H.R., Sharma, O.P., Yadav, L. R and Choudhary, G.L. 2011. Effect of organic sources and chemical fertilizers on productivity of mungbean. Journal of Food Legumes. 24(4): 324-326.

CMIE 2014-15. Centre for Monitoring Indian Economy, Apple Heritage, Mumbai.

Das, R., Patra, B.C., Pathak, A and Mandal., M.K. 2015. Influence of phosphorus, VAM and PSB on the performance of summer green gram. Environment and Ecology. 33(4): 1430-1435.

Dhakal, Y., Meena, R.S and Kumar, S. 2016. Effect of INM on nodulation, yield, quality and available nutrient status in soil after harvest of green gram. Legume Research. 39(4): 590-594.

Dhewa, J., Singh, Y., Sulochana and Bajia, R., 2015. Effect of phosphorus levels and PSB on growth indices and yield of green gram [Vigna radiata (L.)] Under custard apple (Annona squamosa) based on agrihorti System. The Bioscan. 10(3): 1317-1320.

Jat, S.L., Prasad, K and Parihar, C.M., 2012. Effect of organic manuring on productivity and economics of mungbean (Vigna radiata $\mathrm{L}$ ). Annals of Agricultural Research. 33(1\&2): 17-20.

Kadam, R., Kalegore, N.K and Patil, R. 2014. Influence of phosphorus, vermicompost and PSB on yield attributes, seed yield and quality of black gram. Advance Research Journal of Crop Improvement. 5(1): 7-10.

Kumar, S., Tomar, S and Tomar, T.S. 2014. Integrated phosphorus management in black gram (Vigna mungo) in western Uttar Pradesh during summer season. Annals of Agricultural Research. 35(3): 290-297.

Kumawat, A., Pareek, B.L and Yadav, R.S. 2010. Response of green gram (Vigna radiata) to biofertilizers under different fertility levels. Indian Journal of Agricultural Sciences. 80 (7): 655-657.

Rani, M., Prakash, V and Khan, K. 2016. Response of mungbean [Vigna radiata (L.) Wilczek] to phosphorus and 
sulphur and PSB during summer season. Agricultural Science Digest. 36(2): 146148.

Rathour, D., Sadhu, A.C and Suryawanshi, P.K., 2014. Integrated phosphorus management in summer green gram (Vigna radiata L.). Advance Research Journal of Crop Improvement. 5(1): 5759.

Singh, S., Malik, J.K., Thenua, O.V.S and Jat, H.S. 2013. Effect of phosphorus and bio-fertilizer on productivity, nutrient uptake and economics of pigeonpea (Cajanus cajan $)+$ mungbean
(Phaseolus radiatus) inter cropping system. Legume Research. 36(1): 41-48.

Tak, S., Sharma, S.K and Reager, M.L. 2013. Growth attributes and nutrients uptake of green gram as influenced by vermicompost and zinc in ari western Rajasthan. Advance Research Journal of Crop Improvement. 4(1): 65-69.

Vibha, Kumari, G and Nidhi. 2014. Impact of phosphate solubilising fungi on the soil nutrient status and yield mungbean (Vigna radiate L) crop. Annals of Agricultural research. 32(2): 136-143.

\section{How to cite this article:}

Bhavya, G., K. Chandra Shaker, G. Jayasree and Malla Reddy, M. 2018. Effect of Phosphorus, Biofertilizers and Organic Manures on Root Nodulation and Productivity of Green Gram (Vigna radiata L.). Int.J.Curr.Microbiol.App.Sci. 7(06): 1140-1145.

doi: https://doi.org/10.20546/ijcmas.2018.706.135 